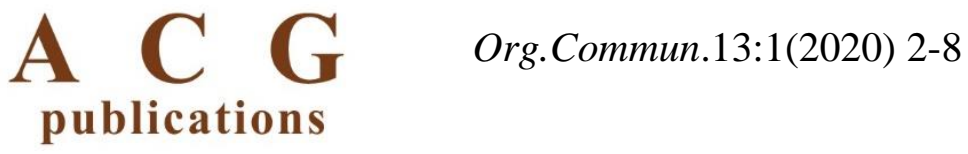

organic communications

\title{
Microwave-assisted synthesis of some new bis-1,3-benzoxazines and their antimicrobial activity
}

\author{
Avinash Shinde $\odot^{1 *}$, Nagesh Deshmukh $\oplus^{1}$ and Sainath Zangade $\oplus^{2}$ \\ ${ }^{I}$ Department of Chemistry, N.E.S.Science College, Nanded (MS), 431605, India \\ ${ }^{2}$ Department of Chemistry, M.P. College, Palam, Parbhani (MS), 431720, India
}

(Received January 11, 2020; Revised March 12, 2020; Accepted March 18, 2020 )

\begin{abstract}
A series of bis-1, 3-benzoxazines (3a-f) were synthesized from reduced product of propane-1, 3-diamine Schiff bases in the presence of formalin under conventional heating and microwave irradiation. The structures of newly synthesized diamines and bis-1, 3-benzoxazines were established on the basis of spectroscopic data. Further, all the synthesized compounds were screened for antimicrobial activity. Some of the compounds showed very good activity compared to standard drugs against all pathogenic bacteria and fungi.
\end{abstract}

Keywords: Bis-schiff bases, bis-1, 3-propane diamines, microwave irradiation, antimicrobial activity. C2020 ACG Publications. All right reserved.

\section{Introduction}

3, 4-Dihydro-2H-1,3-benzoxazines are bicyclic heterocycles that are of significant interest in the polymeric and pharmacological field. Benzoxazines are important class of benzfused heterocycles with wide spectrum of biological activity such as antimicrobial ${ }^{1,2}$, analgesics ${ }^{3}$, antibacterial ${ }^{4}$, neuoprotective ${ }^{5}, \mathrm{D}_{2}$ receptor antagonistic activity ${ }^{6}$, antimycobacterial ${ }^{7}$, antiviral ${ }^{8}$, antifungal activity ${ }^{9}$ these type of compounds have been important subject of researchers. In addition, N-substituted 3,4dihydro-2H-1,3-benzoxazines are potential intermediates for the preparation of phenol formaldehyde resins ${ }^{10}$. Hence the synthesis of these compounds including attracted great interest. Several methods have been reported for the preparation of these compounds in literature for example, an important method was developed by using mannich-type condensations of phenol, with primary amines and two equivalent of formaldehyde ${ }^{11}$. Condensation of $o$-aminomethyl phenol with an aldehyde or ketones provided another route ${ }^{12}$. Reactions of primary amines with oxygen-containing dihalocompounds established a way to prepare 3,4-dissymmetric-substituted 3,4-dihydro-1,3-benzoxazines ${ }^{13}$. Recently, rhodiumcatalyzed reactions of 2-(alkenyloxy)benzylamines have been developed as a way to generate 3,4dihydro-1,3-benzoxazines an allylic cleavage followed by regioselective carbonylation at the internal carbon atom ${ }^{14}$. However, some drawback existed in previous methods. Moreover, the presence of some functional groups in the benzoxazine is incompatible with the use of this direct synthetic methodology. This is the case of the phenolic group that is desirable to prepare new polymeric materials with welldefined properties. This fact and the aim to prepare the bis-1,3-benzoxazine and its antimicrobial studies lead us to explore the utility of alternative synthetic routes.

The microwave induced enhancement of organic reactions is currently a focus of attention for chemists due to the decreased reaction time, improved yields and easier work up as compared to conventional methods ${ }^{15}$. In microwave synthesis, to avoid accidents low boiling, toxic and poisonous solvents are often avoided. The use of microwave for the synthesis of organic compounds has proved to

*Corresponding author: E-Mail: drats04@gmail.com 
be efficient, safe and environmentally benign techniques with shorter reaction time ${ }^{16}$. In view of above findings, the synthesis of new biologically active bis-1,3-benzoxazine derivatives under conventional and non conventional(microwave irradiation) methods, are reported herein.

\section{Experimental}

\subsection{Chemical Materials and Apparatus}

Melting points were determined in an open capillary tube and are uncorrected. The chemicals and solvents used were of laboratory grade and were purified. Purity of compounds and completion of the reaction was monitored by thin layer chromatography using hexane/ethyl acetate (7:3) as the mobile phase on precoated sheetes of silica gel-G (Merck, Germany) using iodine vapour for detection. IR spectra were recorded in $\mathrm{KBr}$ on a Perkin-Elmer spectrometer. ${ }^{1} \mathrm{H}$ NMR spectra were recorded in DMSO- $_{6}$ with an Avance spectrometer (Bruker, Germany) at $400-\mathrm{MHz}$ frequency using TMS as an internal standard. Elemental analyses were performed on a Perkin-Elmer 240 CHN elemental analyzer.Synthos-3000, Anton Paar reaction system was used for microwave synthesis.

\subsection{General Procedure for $N^{1}, N^{3}$-dibenzylpropane-1,3-diamines (2a-f)}

Sodium borohydride $(0.04 \mathrm{~mol})$ was added to a solution of bis-Schiff bases 1a-f $(0.01 \mathrm{~mol})$ in $\mathrm{MeOH}(10 \mathrm{~mL})$ and the mixture was stirred for $30 \mathrm{~min}$. at room temperature. The solid separated, on pouring the reaction mixture into ice-cold water, was filtered and recrystallized from petroleum ether to get 2a-f.

\subsection{Physical and Spectral Data for $2 a-f$}

2,2'-((propane-1,3-diylbis(azanediyl))bis(methylene))diphenol) (2a): White solid, IR (KBr) $3450 \mathrm{~cm}^{-1}(-$ $\mathrm{OH}), 3305 \mathrm{~cm}^{-1}(-\mathrm{NH}), 2924 \mathrm{~cm}^{-1}\left(-\mathrm{CH}\right.$ of $\left.-\mathrm{CH}_{2}\right) ;{ }^{1} \mathrm{H}$ NMR (DMSO d 6 ) $\delta: 1.60\left(\mathrm{~m}, 2 \mathrm{H}, \mathrm{CH}_{2}\right), 2.52(\mathrm{t}$, $\left.J=4.2 \mathrm{~Hz}, 4 \mathrm{H}, 2-\mathrm{NCH}_{2}\right), 3.75\left(\mathrm{~s}, 4 \mathrm{H}, 2-\mathrm{CH}_{2}\right), 4.32(\mathrm{~s}, 2 \mathrm{H}, 2-\mathrm{NH}), 6.80(\mathrm{dd}, J=7.1$ and $2.1 \mathrm{~Hz} 2 \mathrm{H}), 6.85$ (dd, $J=7.1$ and $2.1 \mathrm{~Hz}, 2 \mathrm{H}), 6.87(\mathrm{dd}, J=7.3$ and $2.1 \mathrm{~Hz}, 2 \mathrm{H}), 7.35(\mathrm{dd}, J=7.3$ and $2.1 \mathrm{~Hz}, 2 \mathrm{H}$ ), 10.22 (s, $2 \mathrm{H}, 2 \mathrm{Ar}-\mathrm{OH}$ ); Anal Calcd for $\mathrm{C}_{17} \mathrm{H}_{22} \mathrm{~N}_{2} \mathrm{O}_{2}$ (286): C 71.32; H 7.69; N 9.79. Found C 71.25; H 7.50; N 9.85 .

2,2'-((propane-1,3-diylbis(azanediyl))bis(methylene))bis(4-bromophenol) (2b): Pale yellow solid, IR (KBr) $3470 \mathrm{~cm}^{-1}(-\mathrm{OH}), 3325 \mathrm{~cm}^{-1}(-\mathrm{NH}), 2940 \mathrm{~cm}^{-1}\left(-\mathrm{CH}\right.$ of $\left.-\mathrm{CH}_{2}\right) ;{ }^{1} \mathrm{H}$ NMR (DMSO d 6 ) $\delta: 1.68(\mathrm{~m}$, $\left.2 \mathrm{H}, \mathrm{CH}_{2}\right), 2.60$ (t, $\left.J=4.2 \mathrm{~Hz}, 4 \mathrm{H}, 2-\mathrm{NCH}_{2}\right), 3.79$ (s, 4H, 2- $\left.\mathrm{CH}_{2}\right), 4.40$ (s, 2H, 2-NH), 6.70 (dd, $J=7.3$ and $2.3 \mathrm{~Hz}, 2 \mathrm{H}), 7.20$ (d, $J=7.3 \mathrm{~Hz}, 2 \mathrm{H}), 7.30$ (d, $J=2.3 \mathrm{~Hz}, 2 \mathrm{H}), 11.10$ (s, 2H, 2Ar-OH); Anal Calcd for $\mathrm{C}_{17} \mathrm{H}_{20} \mathrm{Br}_{2} \mathrm{~N}_{2} \mathrm{O}_{2}$ (442): C 46.15; H 4.52; N 6.33. Found C 46.00; H 4.75; N 6.15.

6,6'-((propane-1,3-diylbis(azanediyl))bis(methylene))bis(2,4-dibromophenol) (2c): Yellow solid, IR (KBr) $3480 \mathrm{~cm}^{-1}(-\mathrm{OH}), 3340 \mathrm{~cm}^{-1}(-\mathrm{NH}), 2960 \mathrm{~cm}^{-1}\left(-\mathrm{CH}\right.$ of $\left.-\mathrm{CH}_{2}\right) ;{ }^{1} \mathrm{H}$ NMR (DMSO d 6$) \delta: 1.75(\mathrm{~m}$, $\left.2 \mathrm{H}, \mathrm{CH}_{2}\right), 2.69$ (t, J=5.8 Hz 4H, 2- $\left.\mathrm{NCH}_{2}\right), 3.80$ (s, 4H, 2- $\left.\mathrm{CH}_{2}\right), 4.48$ (s, 2H, 2-NH), 6.95 (d, J=2.5 Hz, $2 \mathrm{H}), 7.65(\mathrm{~d}, J=2.5 \mathrm{~Hz}, 2 \mathrm{H}), 11.15(\mathrm{~s}, 2 \mathrm{H}, 2 \mathrm{Ar}-\mathrm{OH})$; Anal Calcd for $\mathrm{C}_{17} \mathrm{H}_{18} \mathrm{Br}_{4} \mathrm{~N}_{2} \mathrm{O}_{2}$ (598): C 34.11; $\mathrm{H}$ $3.01 ; \mathrm{N} 4.68$. Found C 34.01; H 3.00; N 4.10.

2,2'-((propane-1,3-diylbis(azanediyl))bis(methylene))bis(4-chlorophenol) (2d): White solid, IR ( $\mathrm{KBr})$ $3472 \mathrm{~cm}^{-1}(-\mathrm{OH}), 3330 \mathrm{~cm}^{-1}(-\mathrm{NH}), 2945 \mathrm{~cm}^{-1}\left(-\mathrm{CH}\right.$ of $\left.-\mathrm{CH}_{2}\right) ;{ }^{1} \mathrm{H}$ NMR (DMSO d $) \delta: 1.69(\mathrm{~m}, 2 \mathrm{H}$, $\left.\mathrm{CH}_{2}\right), 2.59$ (t, $\left.J=4.6 \mathrm{~Hz}, 4 \mathrm{H}, 2-\mathrm{NCH}_{2}\right), 3.81\left(\mathrm{~s}, 4 \mathrm{H}, 2-\mathrm{CH}_{2}\right), 4.43(\mathrm{~s}, 2 \mathrm{H}, 2-\mathrm{NH}), 6.75$ (dd, $J=7.4$ and $2.5 \mathrm{~Hz}, 2 \mathrm{H}), 7.20(\mathrm{~d}, J=7.4 \mathrm{~Hz}, 2 \mathrm{H}), 7.30(\mathrm{~d}, J=2.5 \mathrm{~Hz}, 2 \mathrm{H}), 11.10(\mathrm{~s}, 2 \mathrm{H}, 2 \mathrm{Ar}-\mathrm{OH})$; Anal Calcd for $\mathrm{C}_{17} \mathrm{H}_{20} \mathrm{Cl}_{2} \mathrm{~N}_{2} \mathrm{O}_{2}$ (354.9): C 57.48; H 4.79; N 7.88. Found C 57.65; H 4.85; 7.90

6,6'-((propane-1,3-diylbis(azanediyl))bis(methylene))bis(2,4-diiodophenol) (2e): Orange solid, IR (KBr) $3482 \mathrm{~cm}^{-1}(-\mathrm{OH}), 3345 \mathrm{~cm}^{-1}(-\mathrm{NH}), 2965 \mathrm{~cm}^{-1}\left(-\mathrm{CH}\right.$ of $\left.-\mathrm{CH}_{2}\right) ;{ }^{1} \mathrm{H}$ NMR (DMSO d$) \delta: 1.76(\mathrm{~m}$, $\left.2 \mathrm{H}, \mathrm{CH}_{2}\right), 2.70\left(\mathrm{t}, J=5.9 \mathrm{~Hz}, 4 \mathrm{H}, 2-\mathrm{NCH}_{2}\right) 3.82\left(\mathrm{~s}, 4 \mathrm{H}, 2-\mathrm{CH}_{2}\right), 4.50(\mathrm{~s}, 2 \mathrm{H}, 2-\mathrm{NH}), 7.15(\mathrm{~d}, J=2.6 \mathrm{~Hz}$, $2 \mathrm{H}), 7.70(\mathrm{~d}, J=2.6 \mathrm{~Hz}, 2 \mathrm{H}), 11.20(\mathrm{~s}, 2 \mathrm{H}, 2 \mathrm{Ar}-\mathrm{OH})$; Anal Calcd for $\mathrm{C}_{17} \mathrm{H}_{18} \mathrm{I}_{4} \mathrm{~N}_{2} \mathrm{O}_{2}$ (790): $\mathrm{C} 25.82 ; \mathrm{H}$ 2.22; N 3.54. Found C 25.70; H 2.30; N 3.45. 
2f, 2'-((propane-1,3-diylbis(azanediyl))bis(methylene))bis(4-methylphenol) (2f): White solid, IR (KBr) $3470 \mathrm{~cm}^{-1}(-\mathrm{OH}), 3325 \mathrm{~cm}^{-1}(-\mathrm{NH}), 2940 \mathrm{~cm}^{-1}\left(-\mathrm{CH}\right.$ of $\left.-\mathrm{CH}_{2}\right) ;{ }^{1} \mathrm{H}$ NMR (DMSO d $) \delta: 1.68(\mathrm{~m}, 2 \mathrm{H}$, $\left.\mathrm{CH}_{2}\right), 2.30\left(\mathrm{~s}, 6 \mathrm{H}, 2-\mathrm{CH}_{3}\right) 2.55\left(\mathrm{t}, J=4.2 \mathrm{~Hz}, 4 \mathrm{H}, 2-\mathrm{NCH}_{2}\right), 3.79$ (s, 4H, 2- $\left.\mathrm{CH}_{2}\right), 4.40(\mathrm{~s}, 2 \mathrm{H}, 2-\mathrm{NH})$, $6.60(\mathrm{dd}, J=7.1$ and $2.0 \mathrm{~Hz}, 2 \mathrm{H}), 7.20(\mathrm{~d}, J=7.1 \mathrm{~Hz}, 2 \mathrm{H}), 7.30(\mathrm{~d}, J=2.0 \mathrm{~Hz} 2 \mathrm{H}), 11.00$ (s, 2H, $2 \mathrm{Ar}-\mathrm{OH})$; Anal Calcd for $\mathrm{C}_{19} \mathrm{H}_{26} \mathrm{~N}_{2} \mathrm{O}_{2}$ (314): C 72.61; H 8.28; N 8.91. Found C 72.50; H 8.40; $\mathrm{N}$ 8.70.

\subsection{General Procedure for the 1,3-benzoxazines (3a-f)}

\subsubsection{Conventional Method}

A mixture of 2,2 [propane-1,3-diylbis(iminomethanediyl)]bis(substituted phenol) 2 (0.005 $\mathrm{mol}$ ) and formalin $(35 \%, \mathrm{w} / \mathrm{v}, 0.010 \mathrm{~mol})$, in $30 \mathrm{~mL}$ absolute ethanol was refluxed for 3-4 hrs. The solid separated, on pouring the reaction mixture into ice-cold water, was filtered and recrystallized from ethanol to get 3a-f.

\subsubsection{Microwave Method}

A homogenous mixture of 2,2 [propane-1,3-diylbis(iminomethanediyl)]bis(substituted phenol) 2 ( $0.005 \mathrm{~mol})$ and formalin $(35 \%, \mathrm{w} / \mathrm{v}, 0.010 \mathrm{~mol})$, was taken in a glass vial equipped with cap and then subjected to microwave irradiation at $100 \mathrm{~W}$ for 5-10 min. progress of the reaction was monitored by TLC. After completion of the reaction, the reaction mixture was poured in cold water. The solid that formed was filtered, dried and recrystalized from ethanol to afford the pure bis-1, 3benzoxazines 3a-f.

\subsubsection{Physical and Spectral Data for $3 a-f$}

1,3-bis(2H-benzo[e][1,3]oxazin-3(4H)-yl)propane (3a): White solid, IR ( $\mathrm{KBr}) 3070 \mathrm{~cm}^{-1}(-\mathrm{CH}$ of $\left.\mathrm{CH}_{2}\right), 1148 \mathrm{~cm}^{-1}(-\mathrm{C}-\mathrm{O}) ;{ }^{1} \mathrm{H}$ NMR (DMSO d 6 ) $\delta: 1.50\left(\mathrm{~m}, 2 \mathrm{H}, \mathrm{CH}_{2}\right), 2.39\left(\mathrm{t}, J=4.1 \mathrm{~Hz}, 4 \mathrm{H}, 2-\mathrm{NCH}_{2}\right), 4.58$ (s, 4H, rings, 2- $\left.\mathrm{NCH}_{2}\right), 5.50\left(\mathrm{~s}, 4 \mathrm{H}\right.$, rings $\left.2-\mathrm{OCH}_{2}\right), 6.75(\mathrm{dd}, J=7.0$ and $2.1 \mathrm{~Hz}, 2 \mathrm{H}) 6.80(\mathrm{dd}, J=7.0$ and $2.1 \mathrm{~Hz}, 2 \mathrm{H}), 6.85(\mathrm{dd}, J=7.3 \& 2.0 \mathrm{~Hz}, 2 \mathrm{H}), 7.30(\mathrm{dd}, J=7.2 \& 2.1 \mathrm{~Hz} 2 \mathrm{H})$; Anal Calcd for $\mathrm{C}_{19} \mathrm{H}_{22} \mathrm{~N}_{2} \mathrm{O}_{2}(310)$ : C 73.54; H 7.69; N 9.03. Found C 73.50; H 7.85; N 9.75.

1,3-bis(6-bromo-2H-benzo[e][1,3]oxazin-3(4H)-yl)propane (3b): White solid, IR (KBr) $3075 \mathrm{~cm}^{-1}(-$ $\mathrm{CH}$ of $\left.-\mathrm{CH}_{2}\right), 1155 \mathrm{~cm}^{-1}(-\mathrm{C}-\mathrm{O}) ;{ }^{1} \mathrm{H}$ NMR $\left(\mathrm{DMSO} \mathrm{d}_{6}\right) \delta: 1.52\left(\mathrm{~m}, 2 \mathrm{H}, \mathrm{CH}_{2}\right), 2.42(\mathrm{t}, J=4.3 \mathrm{~Hz}, 4 \mathrm{H}, 2-$ $\left.\mathrm{NCH}_{2}\right), 4.60\left(\mathrm{~s}, 4 \mathrm{H}\right.$, rings 2- $\left.\mathrm{NCH}_{2}\right), 5.55\left(\mathrm{~s}, 4 \mathrm{H}\right.$, rings $\left.2-\mathrm{OCH}_{2}\right), 6.65(\mathrm{dd}, J=7.2$ and $2.2 \mathrm{~Hz}, 2 \mathrm{H}), 7.15$ $(\mathrm{d}, J=7.2 \mathrm{~Hz}, 2 \mathrm{H}), 7.30(\mathrm{~d}, J=2.2 \mathrm{~Hz}, 2 \mathrm{H})$; Anal Calcd for $\mathrm{C}_{19} \mathrm{H}_{20} \mathrm{Br}_{2} \mathrm{~N}_{2} \mathrm{O}_{2}$ (468): C 48.71; $\mathrm{H} 4.27 ; \mathrm{N}$ 5.98. Found C 48.85; H 4.35; N 6.00

1,3-bis(6,8-dibromo-2H-benzo[e][1,3]oxazin-3(4H)-yl)propane (3c): Brown solid, IR (KBr) $3085 \mathrm{~cm}^{-1}$ $\left(-\mathrm{CH}\right.$ of $\left.-\mathrm{CH}_{2}\right), 1164 \mathrm{~cm}^{-1}(-\mathrm{C}-\mathrm{O}) ;{ }^{1} \mathrm{H}$ NMR (DMSO d 6 ) $\delta: 1.58\left(\mathrm{~m}, 2 \mathrm{H}, \mathrm{CH}_{2}\right), 2.50(\mathrm{t}, J=5.6 \mathrm{~Hz}, 4 \mathrm{H}, 2-$ $\left.\mathrm{NCH}_{2}\right), 4.67$ (s, 4H, rings 2- $\left.\mathrm{NCH}_{2}\right), 5.60\left(\mathrm{~s}, 4 \mathrm{H}\right.$, rings $\left.2-\mathrm{OCH}_{2}\right), 6.90(\mathrm{~d}, J=2.4 \mathrm{~Hz}, 2 \mathrm{H}), 7.55(\mathrm{~d}, J=2.4$ $\mathrm{Hz}, 2 \mathrm{H}$ ); Anal Calcd for $\mathrm{C}_{19} \mathrm{H}_{18} \mathrm{Br}_{4} \mathrm{~N}_{2} \mathrm{O}_{2}$ (626): C 36.42; $\mathrm{H} 2.87 ; \mathrm{N}$ 4.47. Found $\mathrm{C} 36.50 ; \mathrm{H} \mathrm{2.95;} \mathrm{N}$ 4.35 .

1,3-bis(6-chloro-2H-benzo[e][1,3]oxazin-3(4H)-yl)propane (3d): White solid, IR (KBr) 3078 $\mathrm{cm}^{-1}(-\mathrm{CH}$

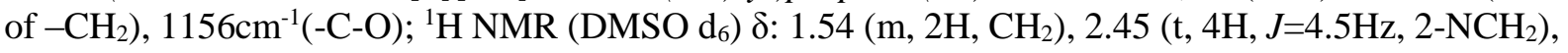
$4.61\left(\mathrm{~s}, 4 \mathrm{H}\right.$, rings $\left.2-\mathrm{NCH}_{2}\right), 5.57\left(\mathrm{~s}, 4 \mathrm{H}\right.$, rings $\left.2-\mathrm{OCH}_{2}\right), 6.70(\mathrm{dd}, J=7.3$ and $2.3 \mathrm{~Hz}, 2 \mathrm{H}), 7.20(\mathrm{~d}$, $J=7.3 \mathrm{~Hz}, 2 \mathrm{H}), 7.30(\mathrm{~d}, J=2.3 \mathrm{~Hz}, 2 \mathrm{H})$; Anal Calcd for $\mathrm{C}_{19} \mathrm{H}_{20} \mathrm{Cl}_{2} \mathrm{~N}_{2} \mathrm{O}_{2}$ (378.9): C 60.17; H 5.32; N 7.39 Found C 60.50; H 5.35; N 7.40

1,3-bis(6,8-diiodo-2H-benzo[e][1,3]oxazin-3(4H)-yl)propane (3e): Yellow solid, IR (KBr) $3083 \mathrm{~cm}^{-1}(-$ $\mathrm{CH}$ of $\left.-\mathrm{CH}_{2}\right), 1160 \mathrm{~cm}^{-1}(-\mathrm{C}-\mathrm{O}) ;{ }^{1} \mathrm{H}$ NMR (DMSO d $\left.{ }_{6}\right) \delta: 1.50\left(\mathrm{~m}, 2 \mathrm{H}, \mathrm{CH}_{2}\right), 2.45\left(\mathrm{t}, 4 \mathrm{H}, 2-\mathrm{NCH}_{2}\right.$, $\mathrm{J}=5.7 \mathrm{~Hz}), 4.52\left(\mathrm{~s}, 4 \mathrm{H}\right.$, rings $\left.2-\mathrm{NCH}_{2}\right), 5.49\left(\mathrm{~s}, 4 \mathrm{H}\right.$, rings $\left.2-\mathrm{OCH}_{2}\right), 7.10(\mathrm{~d}, J=2.4 \mathrm{~Hz} 2 \mathrm{H}), 7.50(\mathrm{~d}, J=2.4$ $\mathrm{Hz}, 2 \mathrm{H}$ ); Anal Calcd for $\mathrm{C}_{19} \mathrm{H}_{18} \mathrm{I}_{4} \mathrm{~N}_{2} \mathrm{O}_{2}$ (814): C 28.00; H 2.21; N 3.43. Found C 28.05; H 2.15; N 3.40.

1,3-bis(6-methyl-2H-benzo[e][1,3]oxazin-3(4H)-yl)propane (3f): White solid, IR (KBr) 3070 $\mathrm{cm}^{-1}(-\mathrm{CH}$ of $\left.-\mathrm{CH}_{2}\right), 1148 \mathrm{~cm}^{-1}(-\mathrm{C}-\mathrm{O}) ;{ }^{1} \mathrm{H}$ NMR (DMSO d 6 $\delta: 1.48\left(\mathrm{~m}, 2 \mathrm{H}, \mathrm{CH}_{2}\right), 2.10\left(\mathrm{~s}, 6 \mathrm{H}, 2-\mathrm{ArCH}_{3}\right), 2.38(\mathrm{t}$, 
$\left.J=4.0 \mathrm{~Hz}, 4 \mathrm{H}, 2-\mathrm{NCH}_{2}\right), 4.55\left(\mathrm{~s}, 4 \mathrm{H}\right.$, rings $\left.2-\mathrm{NCH}_{2}\right), 5.50$ (s, $4 \mathrm{H}$, rings $\left.2-\mathrm{OCH}_{2}\right), 6.55(\mathrm{dd}, J=6.50$ and $2.0 \mathrm{~Hz}, 2 \mathrm{H}), 7.00(\mathrm{~d}, J=6.50 \mathrm{~Hz}, 2 \mathrm{H}), 7.20\left(\mathrm{~d}, J=2.0 \mathrm{~Hz} 2 \mathrm{H}\right.$ ); Anal Calcd for $\mathrm{C}_{21} \mathrm{H}_{26} \mathrm{~N}_{2} \mathrm{O}_{2}$ (338): C 74.55; H 7.69; N 8.28. Found C 74.50; H 7.65; N 8.30

\subsection{Antimicrobial Activity}

Newly synthesized compounds (3a-f) were screened for antimicrobial activity against Grampositive bacteria Staphylococcus aureus (MTCC-96), the Gram-negative bacteria Escherichia coli (MTCC-443) in the nutrient agar media, and fungi Aspergillus niger (MTCC-281) and Aspergillus flavus (MTCC-1323) in sabouraud dextrose medium at 200, 100, 50, 25, and $12.5 \mu \mathrm{g} / \mathrm{mL}$ concentrations by using borth dilution method ${ }^{18-20}$. The minimum inhibitory concentrations (MIC's) values were determined by comparison to ofloxacin and ketoconazole as the reference drugs for bacterial and fungal activity respectively, as shown in table-2. Standard antibiotics ofloxacin and ketoconazole were used as reference drugs at $50,25,12.5 \mu \mathrm{g} / \mathrm{mL}$ concentrations. The minimum inhibitory concentration (MIC) was defined as the lowest concentration of the compound that inhibits the visible growth of microorganism on the plate.

\section{Results and Discussion}

\subsection{Chemistry}

In this article, we report the synthesis of new biologically active bis-1,3-benzoxazines derivatives 3a-f under conventional and non-conventional (microwave irradiation) methods. The synthesis of new derivatives of bis-1,3-benzoxazine (3a-f) was performed as outlined in scheme 1 .

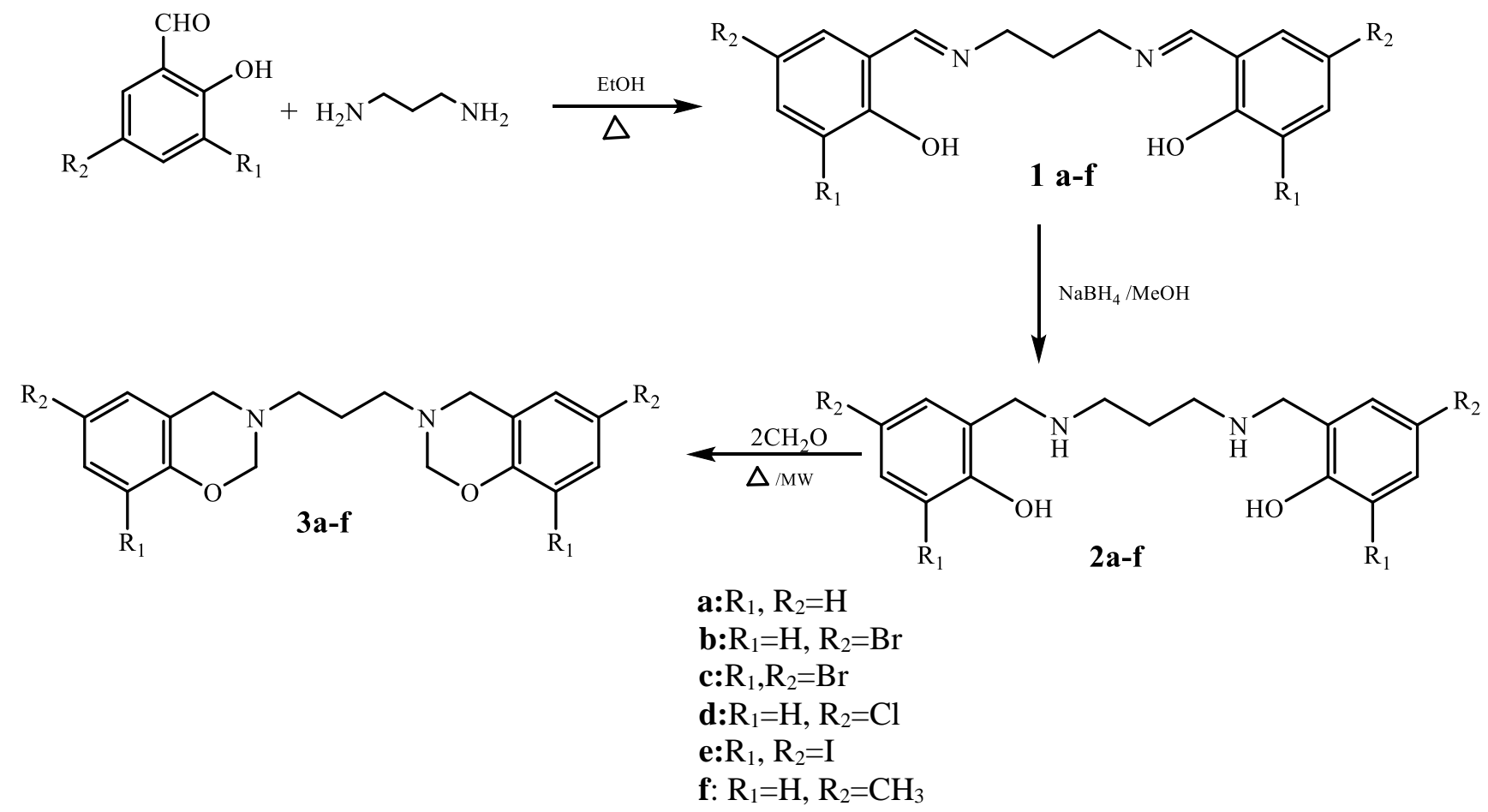

Scheme 1. Synthesis of bis-1, 3-benzoxazines

Our syntheses are based on three step reactions. In our previous study, we reported microwave induced synthesis of bis-Schiff bases of propane-1, 3-diamine. ${ }^{17}$ In the present study, following this procedure, at first we reacted different salicyl aldehydes with 1,3propandiamine to give bis Schiff bases 1a-f which were used for further reactions without characterization. At the second step bis-Schiff bases 1a-f were reduced with $\mathrm{NaBH}_{4}$ to give 
$N^{l}, N^{3}$-dibenzylpropane-1,3-diamines 2a-f. Cyclization of $N^{l}, N^{3}$-dibenzylpropane-1,3-diamines 2a-f with formaldehyde gave benzoxazines 3a-f.

It was found that the synthesis of bis-1,3-benzoxazines 3a-f by conventional methods took a longer time and gave lower yields when compared to the microwave irradiation technique in which the reaction proceeded smoothly with excellent yields, within a 5-10 minutes (Table 1)

Table1. Comparison for the yields of the synthesized compounds 3a-f

\begin{tabular}{cccccc}
\hline Compounds & M.P. ${ }^{\mathbf{}} \mathbf{C}$ & \multicolumn{2}{c}{ Conventional method } & \multicolumn{2}{c}{ MWI } \\
\hline & & t/h & Yield, \% & t/min & Yield, \% \\
\hline 3a & 115 & 3.0 & 65 & 08 & 85 \\
3b & 145 & 3.5 & 60 & 10 & 80 \\
3c & 165 & 4.0 & 60 & 10 & 80 \\
3d & 155 & 3.0 & 62 & 10 & 85 \\
3e & 148 & 4.0 & 61 & 06 & 87 \\
3f & 170 & 3.0 & 60 & 10 & 84 \\
\hline
\end{tabular}

IR spectra of the dibenzylpropane-1,3-diamines 2a-f showed the absorption bands at 3450 and $3300 \mathrm{~cm}^{-1}$ due to $\mathrm{OH}$ and $\mathrm{NH}$ groups respectively. The ${ }^{1} \mathrm{H}$ NMR spectrum of 2a-f showed singlet in between $\delta 3.70-4.00$ is due to benzylic $\mathrm{CH}_{2}$ protons which is directly attached to aromatic ring whereas a broad singlet in between $\delta 4.32-5.00$ is due to $\mathrm{NH}$ protons respectively confirming a reductions. The compounds 2a-f underwent smooth ring closure in presence of formaldehyde, involving internal Mannich reaction to give bis-1, 3-benzoxazines 3a-f. The IR spectrum of 3a-f showed the absence of bands due to $\mathrm{OH}$ and $\mathrm{NH}$ group which were observed in its precursor. Its ${ }^{1} \mathrm{H}$ NMR spectrum displayed two distinct singlet at $\delta 4.10$ and $\delta 5.08$ due to newly formed 1,3-oxazine ring, methylene protons $\left(\mathrm{CH}_{2}\right.$ and $\mathrm{NCH}_{2} \mathrm{O}$ ) respectively confirming cyclization.

\subsection{Antimicrobial Activity}

The investigation of antibacterial and antifungal screening data revealed that all tested compounds 3a-f showed good to moderate inhibition at $12.5-200 \mu \mathrm{g} / \mathrm{mL}$ in DMSO. The compounds 3c, 3d, 3e, showed comparatively good activity against all the bacterial strains. The good activity is attributed to the presence of pharmacologically active $-\mathrm{Br}(\mathbf{3 c}),-\mathrm{Cl}(\mathbf{3 d}),-\mathrm{I}(\mathbf{3 e})$, groups attached to phenyl group at 2,3 and $4^{\text {th }}$ position in bis-benzoxazines. When the substitution of these groups is replaced by hydrogen or another group, a sharp decrease in activity against most of strains was observed. Compound 3a, 3b, 3f, exhibited moderate activity compared to that of standard ofloxacin against all the bacterial strain. Further the result showed that Gram-negative exhibited better activity than Grampositive organism.

Table 2. Antibacterial and Antifungal activity of title compounds 3a-3f

\begin{tabular}{ccccc}
\hline \multicolumn{5}{c}{ MIC* } \\
Entry & (minimum inhibitory concentration \\
3a & S. aureus & E.coli & A.niger & A.flavus \\
3b & 100 & 50 & 200 & 200 \\
3c & 200 & 200 & 100 & 50 \\
3d & 25 & 25 & 25 & 25 \\
3e & 25 & 12.5 & 12.5 & 12.5 \\
3f & 12.5 & 12.5 & 12.5 & 12.5 \\
Ofloxacin & 200 & 200 & 50 & 150 \\
Ketoconazole & 25 & 12.5 & NT & NT \\
\hline
\end{tabular}

* MIC(minimum inhibitory concentration) as given $\mu \mathrm{g} / \mathrm{mL}$. NT: Not tested. 
Compounds 3d, 3e, 3f, showed comparatively good activity against all the fungal strains, while compound 3a, 3b showed moderate activity against the fungal strains. The structures of these compounds contain biologically active, chloro, iodo, bromo and hydroxyl substituted groups.

\section{Conclusion}

A new series of bis-1,3-benzoxazines 3a-f were synthesized under conventional and microwave irradiation conditions. In microwave irradiation method, the reactions were completed in shorter times with better yields compared to the conventional method. All the new compounds were screened for their antimicrobial activities. It was observed that compounds 3c, 3d, 3e exhibited broad spectrum of antibacterial and antifungal activity against all the tested strains compared to the standard drugs at their respective concentrations.

\section{Acknowledgements}

The authors are also thankful to Principal, N.E.S.Science College, Nanded, for providing laboratory facilities and Director Indian Institute of Chemical Technology (IICT), Hyderabad for providing necessary instrumental facilities

\section{Supporting Information}

Supporting information accompanies this paper on http://www.acgpubs.org/journal/organic$\underline{\text { communications }}$

\section{ORCID}

Avinash Shinde: 0000-0001-7898-3252

Nagesh Deshmukh: 0000-0003-0123-379X

Sainath Zangde: 0000-0002-9659-3458

\section{References}

[1] Gomez, P.G.; Pabon, H.P.; Carvajal, M.A.; Rincon, J.M. Synthesis of four benzoxazines and determination of your expectro of antibacterial activity. Rev Colomb. Cienc. Quim. Farm. 1985, 4,15-19.

[2] Waisser, K.; Gregor, K.; Kubicova, L.; Klimesova, V.; Kunes, J.; Machacek, M.; Kaustova, J. New groups of antimycobacterial agents: 6-chloro-3-phenyl-4-thioxo-2H-1,3-benzoxazine-2(3H)-ones and 6-chloro-3phenyl-2H-1,3-benzoxazine-2,4(3H)-dithiones. Eur. J. Med. Chem. 2000, 35,733-741.

[3] Gokhan, N.; Erdogan, H.; Durlu, N.T.; Demirdamar, R. Analgesic activity of acylated 2-benzoxazolinone derivatives. Farmaco 1999, 54, 112-115.

[4] Beach, M.; Frechette, R. 2-Substituted amino and thioalkylbenzoxazine antimicrobial agents. WO Patent Appl. 9728167, 1997.

[5] Kamei, K.; Maeda, N.; Nomura, K.; Shibata, M.; Katsuragi-Ogino, R.; Koyama, M.; Nakajima, M.; Inoue, T.; Ohno, T.; Tatsuoka, T. Synthesis, SAR studies, and evaluation of 1,4-benzoxazepine derivatives as selective 5-HT1A receptor agonists with neuroprotective effect: discovery of Piclozotan. Bioorg .Med. Chem. 2006, 14, 1978-1992.

[6] Ilas, J.; Anderluh, P.S.; Dolenc, M.S.; Kikelj, D. Recent advances in the synthesis of 2H-1,4-benzoxazin3-(4H)-ones and 3,4-dihydro-2H-1,4-benzoxazines. Tetrahedron 2005, 61, 7325-7348.

[7] Waisser, K.; Perina, M.; Kunes, J.; Klimesova, V.; Kaustova,; J. 3-Benzyl-2H-1,3-benzoxazine-2,4(3H)diones, a new group of antimycobacterial compounds against potentially pathogenic strains. Farmaco 2003, 58, 1137-1149.

[8] Wittmann, S.; Scherlitz-Hofmann, I.; Mollmann, U.; Ankel-Fuchs, D.; Heinisch, L. 8-Acyloxy-1,3benzoxazine-2,4-diones as siderophore components of antibiotics. Arzneim-Forsch Drug Res. 2000, 50, 752-757. 
[9] Waisser, K.; Kubicova, L.; Buchta, V.; Kubanova, P.; Bajerova, K.; Jiraskova, L. In vitro antifungal activity of 3-phenyl-2Hbenzoxazine-2,4(3H)-diones. Folia Microbiol. 2002, 47, 488-492.

[10] Kopf, P.W.; Wagner, E.R. Formation and cure of novolacs: NMR study of transient molecules. J. Polym. Sci. Polym. Chem. Ed. 1973, 11, 939-960.

[11] Burke, W.J. 3,4-Dihydro-1,3,2H-benzoxazines. Reaction of $p$-substituted phenols with N,Ndimethylolamines. J. Am. Chem. Soc. 1949, 71, 609.

[12] McDonagh, A.F.; Smith, H.E. Ring-chain tautomerism of derivatives of o-hydroxybenzylamine with aldehydes and ketones. J Org Chem. 1968, 33, 8-12.

[13] Colin, J.L.; Loubinoux, B. Nouvelle voie dacces aux dihydro-3,4-2H-benzoxazines-1,3. Tetrahedron Lett. 1982, 23, 4245-4246.

[14] Aghayan, M.; Ghassemzadeh, M.; Hoseini, M.; Bolourtchian, M. Microwave-assisted synthesis of the tetradentate Schiff-bases under solvent-free and catalyst-free condition. Synth Comm. 2003, 33, 521-525.

[15] Tania, R.; Ancker, V.; Gareth, W.V.; Raston, C.L. Benign approaches for the synthesis of bis-imine Schiff bases. Green Chem. 2006, 8, 50-53.

[16] Das, S.; Das, V.K.; Saikia, L.; Thakur, A.J. Environment-friendly and solvent-free synthesis of symmetrical bis-imines under microwave irradiation. Green Chem. Lett. Rev. 2012, 5, 457-474.

[17] Shinde, A.; Zangade, S.; Chavan, S.; Vibhute, Y. Microwave induced synthesis of bis-Schiff bases from propane-1, 3-diamine as promising antimicrobial analogs. Org Comm. 2014, 8, 60-67.

[18] Al-Majmaie, S.; Nahar, L.; Sharples, G.P.; Wadi, K., Sarker, S.D. Isolation and antimicrobial activity of rutin and its derivatives from Ruta chalepensis (Rutaceae) growing in Iraq. Rec. Nat. Prod. 2019 13, 64 70 .

[19] Diwan, F.A; Shaikh, M.H.; Shaikh, M.; Farooqui, M. $\gamma$-Valerolactone: Promising bio-compatible media for the synthesis of 2-arylbenzothiazole derivatives. Org . Comm. 2019, 12, 1-13.

[20] Patel, J.B.; Miller, L.A.; Cockerill, F.R.; Nicolau, D.P.; Bradford, P.A.; Powell, M.; Eliopoulus, G.M.; Swenson, J.M.; Hindler, J.A.; Traczewski, M.M.; Jenkins, S.G.; Turnidge, J.D.; Lewis, J.S.; Weinstein, M.P.; Limbago, B.; Zimmer, B.L. Methods for dilution Antimicrobial susceptibility tests for bacteria that Grow Aerobically Approved Standard 10 ${ }^{\text {th }}$ edition. CLSI Document M07-A10 S1-S15, 2015.

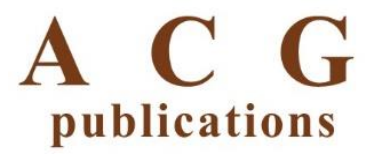

(C) 2020 ACG Publications 